\title{
Your responsibilities as a media spokesperson
}

\section{You must take the initiative.}

The media will not beat a path to your door step. It is your job to reach out and let them know you have a story of interest to their readers/viewers/listeners. To do this well, you must know and understand the different needs of different media.

\section{You must be an educator.}

It is your responsibility to educate the reporter so she/he can communicate your message to others. Provide written background materials but do not assume the reporter has read them. Harried reporters often do not take the time to read these materials but instead expect you to make the issue understandable. Watch the reporter to be sure that she/he is understanding the points you are trying to make.

\section{You must be quotable.}

Statistics are useful as background information but they are generally not quotes. Reporters, especially radio and television reporters, are looking for "sound bites"-a 12- to 20-second statement that puts an issue into perspective. And they are looking to you to deliver it in a way that will make it interesting and alive for their readers/listeners/viewers. Keep in mind

\section{Put C\&RL News on your mailing list}

CERL News likes to include short, practical ideas of interest to our readers. Many of these items are picked up from brief notices read in library newsletters, e.g., the items about parent and staff fundraising on page 373 and Post-its ${ }^{\mathrm{TM}}$ (February 1992) were found in a library newsletter. Grants, acquisitions, and personnel changes are also often picked up from a library newsletter. If your library or institution has a newsletter (print or electronic) please be sure that CGRRL News is on your mailing list. Newsletters should be sent to: Editor, CERL News, $50 \mathrm{E}$. Huron St., Chicago, IL 60611; or e-mail: U38398@UICVM.bitnet. that your audience most likely will not retain facts or figures; they will retain a feeling about you and your message. The goal is to have that audience respect, believe, and trust you.

\section{You must be prepared.}

Before any interview, prepare a "mini-speech"a concise message that you can deliver with feeling, a statement that summarizes the most important idea that you want to communicate. Always be prepared to answer the 5 W's and H and variations on them. Make a list of all the questions you can imagine the reporter will ask. Make note of what questions you would most like (and least like) to be asked. Prepare answers in advance. Review you briefing materials. Have your "quotable quotes" ready. Call Al.A if you need additional information.

\section{You must be in control.}

Being in control means taking proactive steps to ensure that your message is heard, that you get the questions you want and avoid the questions you don't want. Remember, you have not signed a contract promising to meet the reporter's "quotable needs" without getting your own needs met as well. $\mathrm{He} / \mathrm{she}$ can ask the questions and you can answer the questions you choose to hear

\section{You must be accessible.}

Reporters work on tight deadlines and don't always call at the most convenient times. If you develop a reputation for always being in meetings or not returning phone calls promptly, they'll soon stop calling. Make it clear that you wish to be notified immediately if the media calls.

\section{You must be credible.}

The reason some people are quoted over and over in news stories is that they have earned a reputation as being a reliable source of accurate information on particular issues. They are accessible to the media and "good for a quote." You want to be one of those people.

Ed note: These tips are reprinted with permission from the handouts prepared by $A L A$ for a media training workshop. 